\title{
Isolation and Structure Elucidation of Olea Europaea
}

\author{
Khan S*, Iqbal M, Khan D, Badshah S, Bushra and Iqbal N \\ Institute of Chemical Sciences, Gomal University, D.I. Khan, Pakistan \\ *Corresponding author: Dr. Shafiullah Khan, ICS, Gomal University D.I. Khan, KP, \\ Pakistan, Tel: +92 966750359; Email: s.khan@gu.edu.pk
}

\section{Research Article \\ Volume 2 Issue 3}

Received Date: May 08, 2018

Published Date: June 20, 2018

\section{Abstract}

The present study comprises on isolation and structure elucidation of four known compounds for the first time from medicinally important species Olea europaea. The powder material of shade-dried plant of O. europaea was extracted several times in Ethanol. This extract was concentrated with the help of rota-vapour to gain the brownish thick gummy crude. The gummy residue was fractionated into four different fractions on the basis of their polarities i.e. n-hexane, $\mathrm{CH} 2 \mathrm{Cl} 2$, EtOAc and Ethanol. From these fractions, the EtOAc fraction was further carried out to perform the process of column chromatography over silica gel with increasing order of different organic solvents system to obtain different compounds. TLC cards were used to check purify of the isolated compounds in different solvents system. The structures were confirmed through modern spectroscopic techniques as, 1H NMR, 13C NMR, IR, UV and EIMS.

Keywords: Olea europaea; Isolation; Characterization; Compound 1-4

\section{Introduction}

Natural products can be described as products of natural genesis [1]. The term natural product has been differentiated into both limited and controversial points. Simply, the term "natural product" is a small molecule which is formed by a biological source. The natural products research has focus on the chemical properties, bio-synthesis and biological functions of secondary metabolites as a central theme of examine and bordering chemistry and biology [2]. So, simple definition is: A living organism produced a chemical substance; a term normally used in reference to chemical substances found in nature which have characteristic pharmacological impacts [3]. Natural products have an important role in the scientific field of pharmacognosy through its study of identification, isolation and characterization. The American Society of Pharmacognosy characterizes pharmacognosy as "The investigation of natural molecules (normally secondary metabolites) that are helpful for their therapeutic, biological, gustatory, or other utilitarian properties. During the investigation of all biological kingdoms, especially marine invertebrates, plants, fungi and bacteria, these natural species are found as a source of the compounds". In general the word "natural product" is same as "secondary metabolite" [2].

The secondary metabolites are obtained from primary metabolites for example carbohydrates, amino acids and lipids and it can be ordered into few chemical groups like alkaloids, phenyl propanoids, polyketides, tepenoids and phenolics [4-6].

Olea europaea is called Olive commonly [7]. And it exists in the Olea genus of the Oleaceae family [8], of Angiosperm (flowering plants) [9]. It is subjected to the Mediterranean 


\section{International Journal of Pharmacognosy and Chinese Medicine}

regions as from Syria to the south end of the Caspian Sea, Asia and northern Iraq. It is scattered between $30^{\circ}$ to $45^{\circ}$ latitudes in the northern and southern hemispheres and from sea-level to $900 \mathrm{~m}$ altitude. But it's also growth occur at 1,000-3,150 $\mathrm{ft}$ altitude. Sunny day is needed for the production of Olive fruit whereas slight winter chill is also needed. Fruit vernalization period is 7-12 weeks below $8^{\circ} \mathrm{C}$. Below $-10^{\circ} \mathrm{C}$ the tree will be killed due to frostiness. The chill coolness may harm the flowers and fresh shoots while the ripping fruits may also be harmed in the end of the autumn. Shoots and flowers can best grow under the temperatures between $18-22^{\circ} \mathrm{C}$. The flowers are always destroyed during the temperature above $30^{\circ} \mathrm{C}$ in spring while the tree may serve even in the higher temperature throughout summer [10]. It can found in well-drained soil of $\mathrm{pH}$ below 8.5 [11]. It remains green throughout the year, having length of 6-9 m which is equally or sometime slightly less spread. The truck is gray in color massively and bumpy contorted. Mostly trees have spreading crowns and rounded. But in Italy, the trees are cylindrical tall. Leaves are silver green in color having $7.5 \mathrm{~cm}$ size, linear, narrow and opposite with sharp tips and intact margins. Flowers are small creamy white in color. One year old tree has axillary clusters of 15 flowers which bloom in spring.
Juvenile period of seeds are long. Most flowers experience pistil premature birth, leaving just a single to twice fruits for each axil at harvest. Olive fruit is edible having drupes, $4 \mathrm{~cm}$ in size, and green in color during end of the summer and turns into black in color on maturity. Its fruit falls on ripping. Olive's maturation period is 6-8 months. When oil content reaches $20-30 \%$ in olive then it is plucked while table olive is plucked earlier on firming [12]. It have 46 chromosomes i.e. $2 \mathrm{n}=2 \mathrm{x}=46$ and it is a diploid specie [13].

Edible fruit is only produced by Olea europaea specie. No fruit is born on the olive tree for the initial 10-12 years. The fruit growth is slow during the months of spring and summer. But in the month of autumn it grows faster due to water content. The fruit weight is $1-15 \mathrm{~g}$ individually. Oil deposition occur in the fruit during the month of August and in autumn it increases while November to January the fruit turns into black color and oil reaches on its peaks [11]. The mature seed is enclosed with a thin coat that covers the starch filled endosperm. It also surrounds the flat, tapering leaf, roots and stems. Seeds shape and size varies with cultivar. The best development of seed occurs in the month of July to September [14].

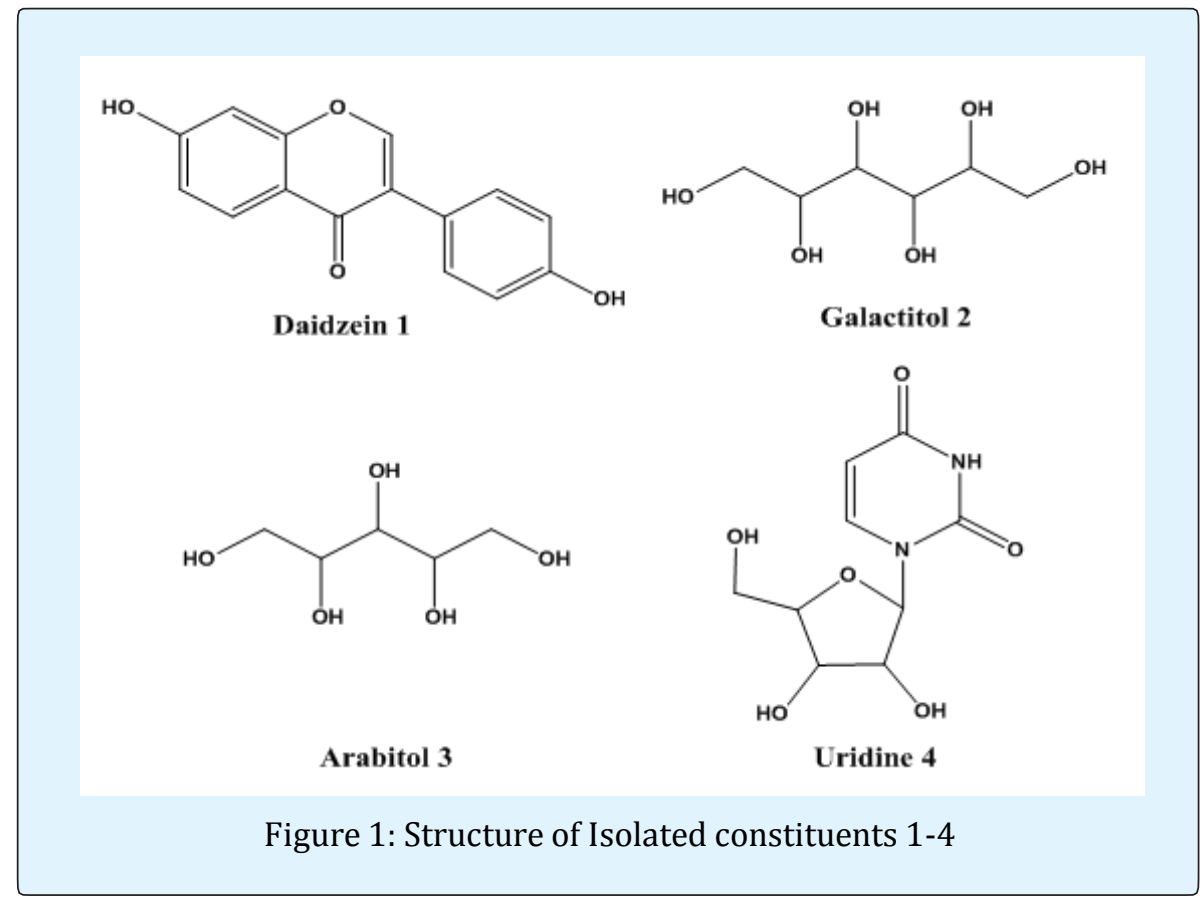

It is economically well known specie having important crop, ornamental [15]. Commercial importance of this specie is for food, cosmetics, lumber and also medicinal products. It is also used as folk medicine for the treatment of neurotic and chronic lung disorder and also for treating neurological disorder, insomnia, heart failure, icterus, tussis, and have wound healing actions. It is also involved in the treatment of various types of acute and chronic inflammatory diseases as a herbal medicine $[8,16]$. 


\section{Results and Discussion}

Ethyl acetate fraction was subjected to column chromatography using silica gel. The column was run with increasing polarity order of different organic solvents as, $n$-hex, $\mathrm{CHCl}_{3}, \mathrm{EtOAc}$ and EtOH to obtain compound 1-4. Purification was done using TLC in different solvent systems.

Daidzein (1) was identified by various analytical techniques and chemical-test. Compound $\mathbf{1}$ obtained as a pale yellow colored crystalline solid with melting point of $315-320^{\circ} \mathrm{C}$. Its molecular formula was determined as $\mathrm{C}_{15} \mathrm{H}_{10} \mathrm{O}_{4}$ by an ion peak at $\mathrm{m} / \mathrm{z} 253.1$ [M-1] +. In the IR spectrum, absorption bands were obtained at $3456 \mathrm{~cm}^{-1}$ (free phenolic $\mathrm{OH}), 1601 \mathrm{~cm}^{-1}(\mathrm{C}=\mathrm{C})$. The compound 1 showed negative Shinoda test which indicated the presence of daidzeinisoflavone. Isolated compound was identical to those spectral data and chemical properties which are reported in earlier for daidzein [17-19].

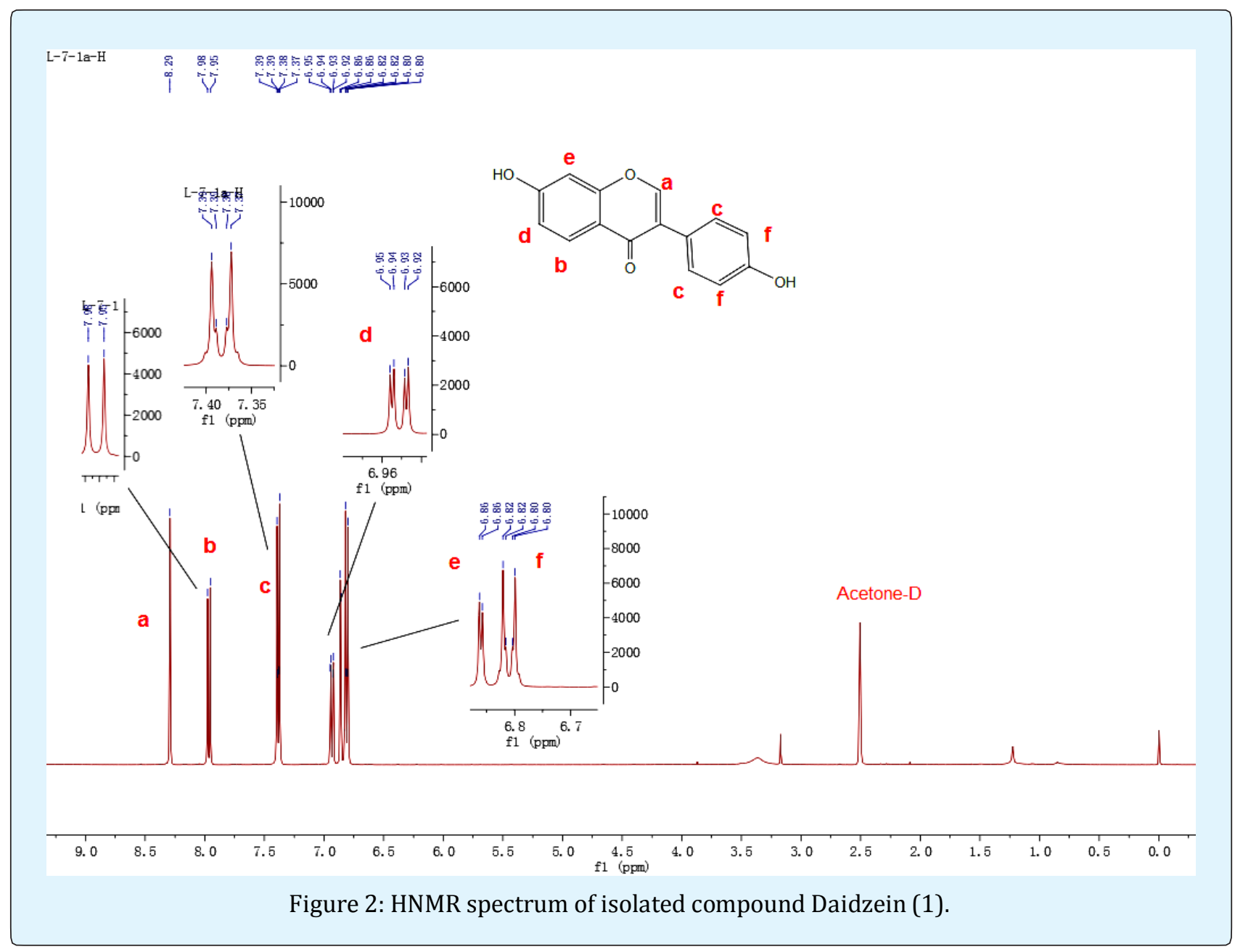

Galactitol (2) was determined by different analytical methods and chemical test. Compound $\mathbf{2}$ was found as amorphous solid with melting point of $189-120^{\circ} \mathrm{C}$. Its molecular formula was determined as $\mathrm{C}_{6} \mathrm{H}_{14} \mathrm{O}_{6}$ by an ion peak at $\mathrm{m} / \mathrm{z} 182.172[\mathrm{M}-1]^{+}$. In the IR spectra, resonating signals at $3600 \mathrm{~cm}^{-1}$ shows the free alcohic $\mathrm{OH}$ group. ${ }^{1 \mathrm{H}}$ NMR and ${ }^{13} \mathrm{C}$-NMR data of galactitol compound is shown in experimental section. In thin layer chromatography (TLC) study, compound illustrated single band on silica gel plate at $\mathrm{Rf}$ value 0.3 in solvent system $\mathrm{n}$-Hexane: Methanol (95:5). Galactitol is a known compoundbecause its spectral data and chemical properties are similar as reported earlier [20,21]. 


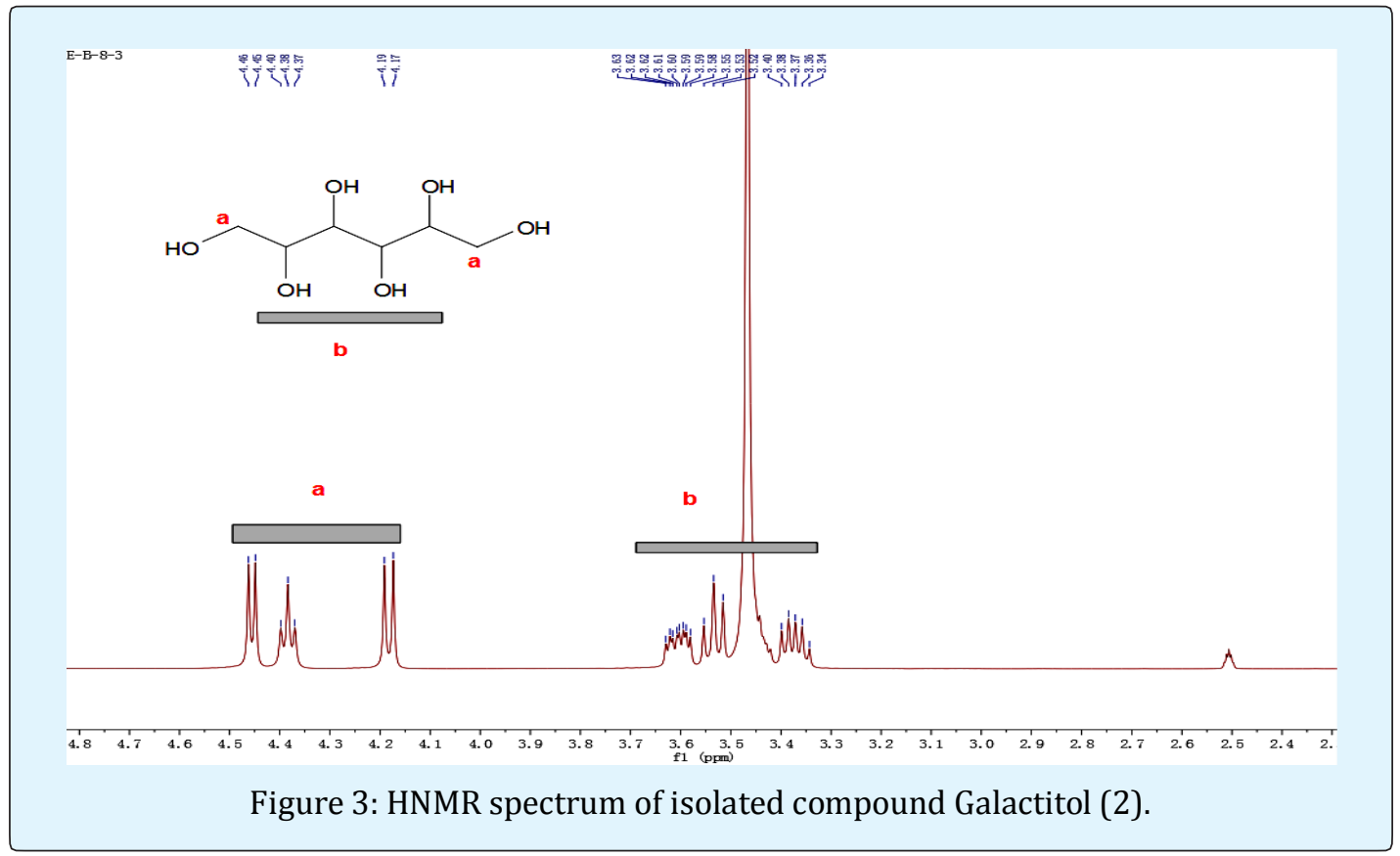

Arabitol (3) compound was identified by analytical methods along with chemical test. Compound3 was isolated as colorless amorphous solid with melting point of $100-103^{\circ} \mathrm{C}$. Its molecular formula was calculated as $\mathrm{C}_{5} \mathrm{H}_{12} \mathrm{O}_{5}$ by an ion peak at $\mathrm{m} / \mathrm{z} 152.145[\mathrm{M}-1]^{+}$. The IR vibrational signals are found at $3624 \mathrm{~cm}^{-1}$ which indicated that compound $\mathbf{3}$ has free alcoholic $\mathrm{OH}$ group. In thin layer chromatography (TLC) analysis, compound showed single band on silica gel plate at $\mathrm{Rf}$ value 0.4 in solvent system $\mathrm{n}$ Hexane: Methanol (90:10). Spectral data and chemical properties of obtained compound were considered to those reported in earlier for arabitol [22].

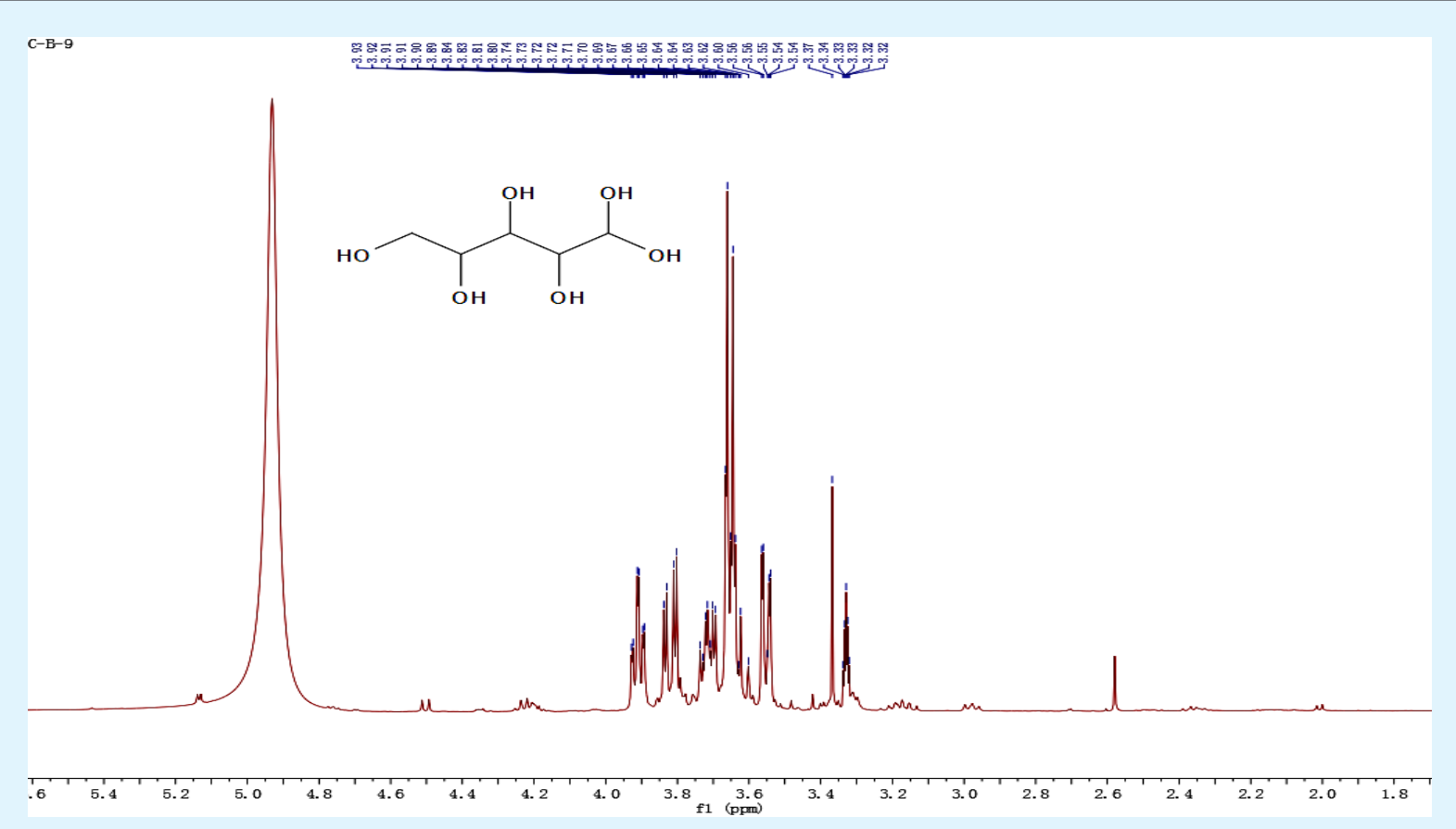

Figure 4: HNMR spectrum of isolated compound Arabitol (3). 


\section{International Journal of Pharmacognosy and Chinese Medicine}

Uridine (4) was obtained by different chemical test and analytical methods. Compound 4 was isolated as colorless crystalline solid with melting point of $163-165^{\circ} \mathrm{C}$. With the help of HREI-MS, its chemical formula was resolute as $\mathrm{C}_{9} \mathrm{H}_{12} \mathrm{~N}_{2} \mathrm{O}_{6}$ by an ion peak at $\mathrm{m} / \mathrm{z} 244[\mathrm{M}-1]{ }^{+}$. In the IR spectrum, different absorption bands were set up at 3640 $\mathrm{cm}^{-1}$ (free alcoholic OH), $1601 \mathrm{~cm}^{-1}(\mathrm{C}=0), 3300 \mathrm{~cm}^{-1}$ (sec amine). In thin layer chromatography (TLC) analysis, compound 4 showed $\mathrm{Rf}$ value 0.5 in solvent system nHexane: Methanol $(80: 20)$ in the form of single band on silica gel plate. Uridine has identical spectral data and chemical properties to those reported in earlier for uridine [23-26].

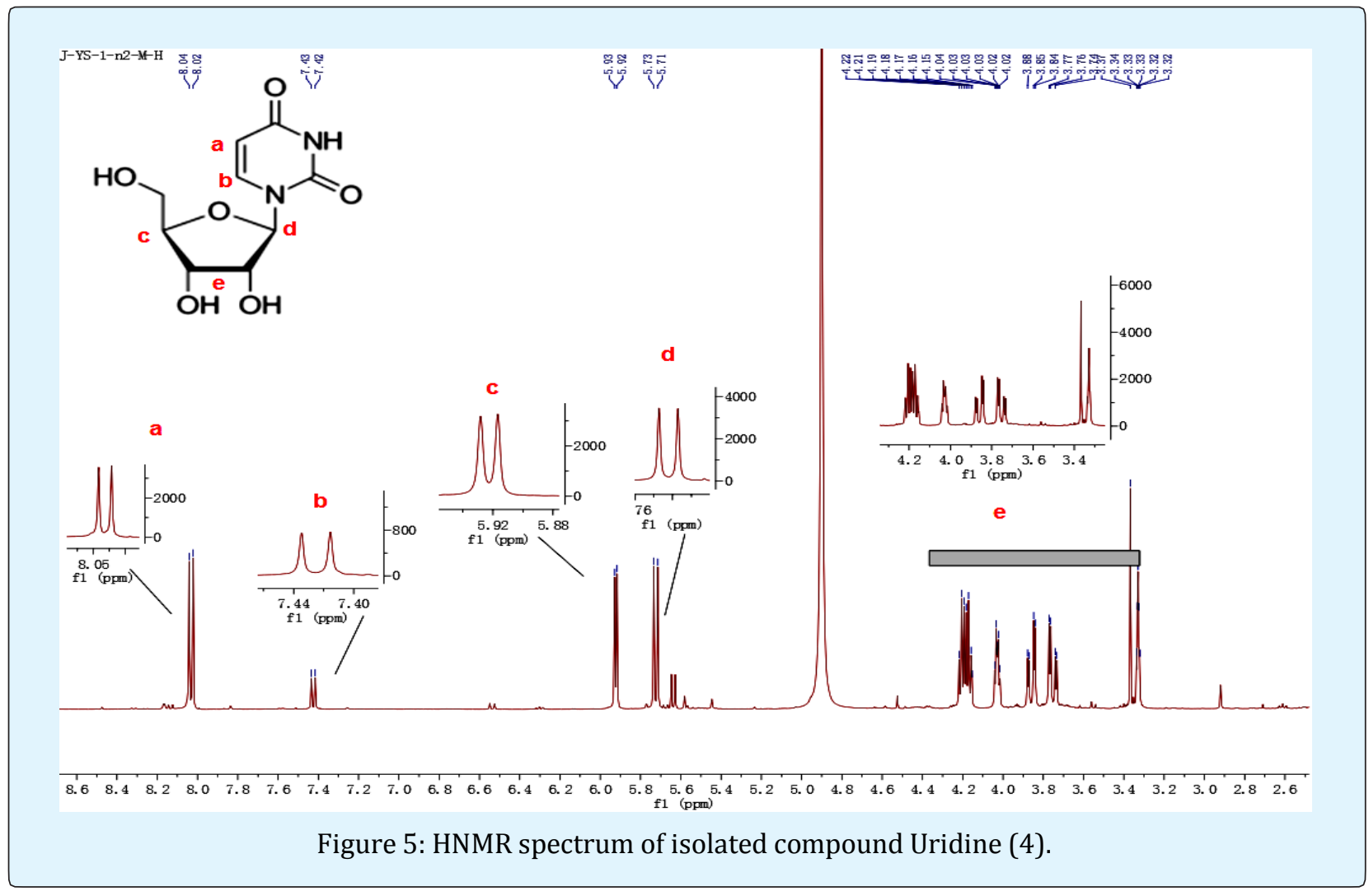

\section{Experimental Section}

\section{Plant Material}

The plant material of Olea europaea was collected from Karak, D.I. Khan, KPK, Pakistan. Prof. Dr. Sadiq Khan, Mufti Mehmood University of Agriculture D.I.K has confirmed the identification of Olea europaea plant.

\section{Extraction and Isolation}

The branches and leaves of plant was shade dried for 40 days. The powdered material of shade dried plant of Olea europaea $(3 \mathrm{~kg})$ was extracted 3 times in Ethanol. This extract was concentrated with the help of rota-vapour to gain the brownish thick gummy crude $(98 \mathrm{~g})$. Then this crude was placed in Ethanol and separated into different fractions of $n$-hex (F-1, $15 \mathrm{~g}), \mathrm{CHCl}_{3}(\mathrm{~F}-2,17 \mathrm{~g})$, EtOAc (F-3, $21 \mathrm{~g})$ and $\mathrm{EtOH}(\mathrm{F}-4,15 \mathrm{~g})$.

From these fractions, the EtOAc (F-3, $21 \mathrm{~g})$ fraction was further carried out to perform the process of column chromatography over silica gel with increasing order of different organic solvents polarity like $n$-hex, $\mathrm{CHCl}_{3}$, EtOAc, and $\mathrm{EtOH}$, to obtain different compounds. TLC cards were used to purify the compounds in different solvents system.

\section{Daidzein (1)}

Pale yellow color crystalline (Purity >99\%); IR Spectrum: $1601 \mathrm{~cm}^{-1}, 3456 \mathrm{~cm}^{-1}$; HR-EMIS m/z 253.1 [M-1] + , (for $\left.\mathrm{C}_{15} \mathrm{H}_{10} \mathrm{O}_{4}\right) ;{ }^{1} \mathrm{H}-\mathrm{NMR}: \mathrm{CH}_{3} \mathrm{OD}, 400 \mathrm{MHz} \delta(\mathrm{ppm}): \delta=6.86$ (1H, s, H-1), 6.95 (1H, d, H-3), 7.98 (1H, d, H-4), 8.29 (1H, s, H-7), 7.39 (1H, d, H-2'), 6.82 (1H, d, H-3'), 6.80 (1H, d, H-5'), $6.86(1 \mathrm{H}, \mathrm{d}, \mathrm{H}-6)$; ${ }^{13} \mathrm{C}-\mathrm{NMR}: \mathrm{CH}_{3} \mathrm{OD}, 100 \mathrm{MHz} \delta(\mathrm{ppm})$ : $\delta=102.64$ (C-1), 163.05 (C-2), 115.39 (C-3), 127.73 (C-4), 
176.14 (C-5), 123.0 (C-6), 153.62 (C-7), 157.89 (C-8), 117.03 (C-9), 123.92 (C-1'), 130.53 (C-2'), 115.61 (C-3), 157.61 (C-4'), 115.61 (C-5'), 130.53 (C-6').

\section{Galactitol (2)}

Colorless amorphous solid (Purity $>99 \%$ ); IR Spectrum: $3600 \mathrm{~cm}^{-1}$; HR-EMIS m/z 182.172 [M-1] +, (for $\mathrm{C}_{6} \mathrm{H}_{14} \mathrm{O}_{6}$ ); ${ }^{1} \mathrm{H}-\mathrm{NMR}: \mathrm{CD}_{3} \mathrm{OD}, 400 \mathrm{MHz} \delta(\mathrm{ppm}): \delta=4.46(2 \mathrm{H}, \mathrm{d}, \mathrm{H}-1)$, $3.63(1 \mathrm{H}, \mathrm{m}, \mathrm{H}-2), 3.60(1 \mathrm{H}, \mathrm{t}, \mathrm{H}-3), 3.60(1 \mathrm{H}, \mathrm{t}, \mathrm{H}-4), 3.63$ $(1 \mathrm{H}, \mathrm{m}, \mathrm{H}-5), 4.46(2 \mathrm{H}, \mathrm{d} \mathrm{H}-6) ;{ }^{13} \mathrm{C}-\mathrm{NMR}: \mathrm{CD}_{3} \mathrm{OD}, 100 \mathrm{MHz} \delta$ (ppm): $\delta=64.30$ (C-1), 70.07 (C-2), 71.72 (C-3 \& C-4), 70.07 (C-5), 64.30 (C-6).

\section{Arabitol (3)}

Colorless amorphous solid (Purity $>99 \%$ ); IR Spectrum: $3624 \mathrm{~cm}^{-1}$; HR-EMIS m/z 2.145 [M-1] + ${ }^{+}$(for $\mathrm{C}_{5} \mathrm{H}_{12} \mathrm{O}_{5}$ );

${ }^{1} \mathrm{H}-\mathrm{NMR}: \mathrm{CD}_{3} \mathrm{OD}, 400 \mathrm{MHz} \delta(\mathrm{ppm}): \delta=3.80(2 \mathrm{H}, \mathrm{d}, \mathrm{H}-1)$, $3.91(1 \mathrm{H}, \mathrm{m}, \mathrm{H}-2), 3.60(1 \mathrm{H}, \mathrm{t}, \mathrm{H}-3), 3.71(1 \mathrm{H}, \mathrm{m}, \mathrm{H}-4)$, $3.80(1 \mathrm{H}, \mathrm{d}, \mathrm{H}-5)$; ${ }^{13} \mathrm{C}-\mathrm{NMR}: \mathrm{CD}_{3} \mathrm{OD}, 100 \mathrm{MHz} \delta$ (ppm): $\delta=63.90$ (C-1), 71.0 (C-2), 63.98 (C-3), 73.0 (C-4), 7.98 (C$5)$.

\section{Uridine (4)}

Colorless crystalline solid (Purity $>98 \%$ ); IR Spectrum: $1601 \mathrm{~cm}-1,3300 \mathrm{~cm}-1,3640 \mathrm{~cm}-1$; HR-EMIS m/z 244 [M1] + , (for C9H12N2O6); ${ }^{1} \mathrm{H}-\mathrm{NMR}$ : CD3OD, $400 \mathrm{MHz} \delta$ (ppm): $\delta=8.04(1 \mathrm{H}, \mathrm{d}, \mathrm{H}-2), 7.43(1 \mathrm{H}, \mathrm{d}, \mathrm{H}-3), 5.73(1 \mathrm{H}, \mathrm{d}$, $\mathrm{H}-5), 4.22(1 \mathrm{H}, \mathrm{t}, \mathrm{H}-6), 4.18$ (1H, t $\mathrm{H}-7), 5.93(1 \mathrm{H}, \mathrm{q}, \mathrm{H}-8)$, $3.84(2 \mathrm{H}, \mathrm{d}, \mathrm{H}-9)$; 13C-NMR: CD3OD, $100 \mathrm{MHz} \delta(\mathrm{ppm})$ : $\delta=164.80$ (C-1), 101.28 (C-2), 141.34 (C-3), 151.08 (C-4), 89.27 (C-5), 69.91 (C-6) 74.32 (C-7), 84.96 (C-8), 60.88 (C9).

\section{Acknowledgement}

The authors are thankful to Quaid-i-Azam University, Islamabad Pakistan for support of this research work.

\section{References}

1. Sarker SD, Lutfun N (2012) An introduction to natural products isolation. Natural products isolation. Humana Press, pp: 1-25.

2. Krause J, Gailene T (2013) Discovery, development, and regulation of natural products. Using old solutions to new problems-natural drug discovery in the 21st century. In Tech.

3. Ulbricht C, Basch E, Boon H, Ernst E, Hammerness P, et al. (2005) Safety review of kava (Piper methysticum) by the Natural Standard Research
Collaboration.Expert opinion on drug safety 4(4): 779794.

4. Ramawat KG, Michel MJ (2008) Bioactive molecules and medicinal plants. Berlin, pp: 1-18.

5. Croteau R, Toni MK, Norman GL (2000) Natural products (secondary metabolites). Biochemistry and molecular biology of plants. 24: 1250-1319.

6. Springob K, Kutchan TM (2009) Introduction to the different classes of natural products, in Plant-Derived Natural Products. Springer, New York, pp: 3-50.

7. Sahranavard SM, Kamalinejad M, Faizi M (2014) Evaluation of anti-inflammatory and anti-nociceptive effects of defatted fruit extract of Olea europaea. Iranian journal of pharmaceutical research 14(1): 119123.

8. Elbir M (2015) Characterization of phenolic compounds in olive stones of three moroccan varieties. Maderas. Ciencia y tecnologia 17(3): 479492.

9. Khan Y, Panchal S, Vyas N, Butani A, Kumar V (2007) Olea europaea: a phyto-pharmacological review. Pharmacognosy Reviews 1(1): 114-118.

10. Lim TK (2012) Edible medicinal and non-medicinal plants. Springer. New York, USA: Springer; pp: 656687.

11. Murphy C (2014) Olives: Origins and Development, in Encyclopedia of Global Archaeology. Springer, New York, pp: 5576-5579.

12. Tarentino K (2001) Medicinal Plants of the World, Chemical Constituents, Traditional and Modern Medicinal Uses. Clinical Chemistry 47(8): 1504-1505.

13. Bracci T, Busconi M, Fogher C, Sebastiani L (2011) Molecular studies in olive (Olea europaea L.): overview on DNA markers applications and recent advances in genome analysis. Plant cell reports 30(4): 449-462.

14. Chiappetta A, Innocenzo M (2012) Botanical description Olive Germplasm-The Olive Cultivation, Table Olive and Olive Oil Industry in Italy. In Tech.

15. Naghiloo S (2013) Comparative study of inflorescence development in Oleaceae. American journal of botany 100(4): 647-663. 
16. Kannan $M$, Singh $R$, Kumar A, Jegatheswari $P$, Subburayalu S (2007) Studies on immuno-bioactivities of Nyctanthes arbortristis (Oleaceae). African Journal of Microbiology Research 1(6): 88-91.

17. Kale M, Laddha K (2012) Isolation, characterization and quantification of isoflavone in Momordica dioica roxb. Ex wild (cucurbitaceae) fruits. International Journal of Applied Research in Natural Products 5(4): 28-36.

18. Nazir N, Koul S, Qurishi MA, Taneja SC, Purnima B, et al. (2008) New isoflavones from Iris kashmiriana. Journal of Asian natural products research 10(12): 1137-1141.

19. Caligiani A, Palla G, Maietti A, Cirlini M, Brandolini V (2010) 1H NMR fingerprinting of soybean extracts, with emphasis on identification and quantification of isoflavones. Nutrients 2(3): 280-289.

20. Cui D, Yan M, Wong S, Zhang X, Xu D (1995) Chemical constituents of stems and leaves of Fritillaria ussuriensis Maxim. J. China journal of Chinese materia medica 20(5): 298-320.

21. Zhang Y, Li C, Zhang C, Tao B (2005) Study on the chemical constituents of Buddleja purdomii. Journal of Chinese medicinal materials 28(11): 994-995.
22. Song W, Lin Y, Hu H, Xie Z, Zhang J (2011) Isolation and identification of a novel Candida sp. $\mathrm{H} 2$ producing D-arabitol and optimization of D-arabitol production. Acta microbiologica Sinica 51(3): 332-339.

23. Deng Y, Ding L, Wu SX, Wang HQ (2005) Studies on chemical constituents in herb of Lamium maculatum var. kansuense (II). China journal of Chinese materia medica 30(4): 272-274.

24. Huo C, Zhao YY, Liang H, Lin WH (2005) Studies on chemical constituents in herbs of Acanthus ilicifolius. China journal of Chinese materia medica 30(10): 763765.

25. Zou Z, Yang J (2008) Studies on the chemical constituents of the roots of Anemone altaica. Journal of Chinese medicinal materials 31(1): 49-51.

26. Zoremsiami J, Jagetia GC (2018) The Phytochemical and Thin Layer Chromatograhy Profile of Ethnomedcinal Plant Helicia Nilagirica (Bedd). International Journal of Pharmacognosy and Chinese Medicine 2(2): 1-12.

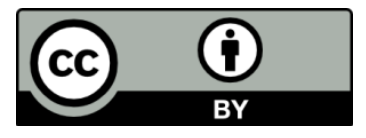

